\title{
Morphological and biochemical characterization of Ralstonia solanacearum (smith) in brinjal (Solanum melongena L.) in Rajasthan (India)
}

\begin{abstract}
Bacterial wilt of brinjal (Solanum melongena L.) is caused by Ralstonia solanacearum (Smith) is an emerging threat and severe problem for production of brinjal in Rajasthan, India. A survey was conducted to know the status of bacterial diseases of brinjal in terms of its incidence, severity and to characterize the pathogen causing the disease. The samples were collected from farmer's field, market and farm storage (houses). Ninty seven seed samples of brinjal were collected from 12 major brinjal growing districts of Rajasthan and subjected to various tests. In dry seed examination, all the seed samples were categorised as asymptomatic, bold discoloured and shrivelled discoloured seeds. The seed samples belongings to 12 districts of Rajasthan revealed asymptomatic $(07.75-97.50 \%)$, moderately discoloured $(04.50-67.50 \%)$ and shrivelled discoloured $(03.25-34.75 \%)$ seeds. The discoloured seeds showed brown black or water soaked symptoms on their surface and such seeds on incubation yielded the bacterium. The standard cultural, morphological, biochemical, molecular characterization and pathogenically tests were carried out for identification of the bacterium. The 97 seed samples of 12 districts of Rajasthan revealed 13-100\% incidence of pathogen on TZC (Tetra Zolium Chloride) agar medium. At seedling stage, seedling shows failure or delayed seeds germination, bacterial oozing and rotting that resulting collapse of hypocotyls and cotyledonary leaves seedling mortality. Thirty two bacterial isolates on the basis of morphological characteristics of colonies and some biochemical tests were obtained from the infected seeds and plant material collected from field during the survey. Pathogenicity test on host plant staple seedling roots, stab inoculation on tender leaves and roots confirmed the bacterium was Ralstonia solanacearum (RS) and HR test (hypersensitivity test) in tobacco leaves with pathogen isolates showed. The causal bacterium was also characterized by biochemical tests and results revealed that the causal organism of bacterial wilt of brinjal was Ralstonia solanacearum.
\end{abstract}

Keywords: ralstonia solanacearum, TZC agar medium, incidence, bacterial wilt, incidence
Volume 8 Issue 3 - 2018

Dilip Kumar Sharma

Vardhaman Mahaveer Open University, India

Correspondence: Dilip Kumar Sharma,Vardhaman Mahaveer Open University, India,

Email, Drdilipsharma 12@gmail.com,dksharma@vmou.ac.in

Received: October 12, 2017 | Published: June 05, 2018

\section{Introduction}

Brinjal (Solanum melongena L.) of family solanaceae is an important vegetable crop growing worldwide. It is grown in the warm areas of Far East, being grown extensively in India, Bangladesh, Pakistan, China, Philippines, France, Italy and United States. It is considered a native to India or major Asia where the major domestication of large fruited cultivars occurred. It has been cultivated in India for the last 4,000 years, although it is often thought of as a Mediterranean or mid-Eastern vegetable. The major brinjal producing states are West Bengal, Orissa, Bihar, Gujarat, Maharashtra, Karnataka, Uttar Pradesh and Andhra Pradesh. In Rajasthan, Alwar, Kota, Jaipur, Sriganganagar and Bharatpur are the major producing districts. The global area under brinjal cultivation has been estimated at 1.85 million $\mathrm{h}$ with total production of brinjal fruit of about 32 million MTs. ${ }^{1-3}$. Bacterial wilt caused by Ralstonia solanacearum ${ }^{4}$ syn. Pseudomonas solanacearum is one of the most destructive diseases of solanaceous crops worldwide. ${ }^{5}$ It is predominant disease in warm humid tropical and temperate regions of the world ${ }^{6,7}$ means receiving global profile. ${ }^{8}$ It has been reported from Switzerland, ${ }^{9}$ London, ${ }^{10}$ Africa, ${ }^{11,12}$ Pakistan. ${ }^{13}$ In India the disease has been reported from the Guwahati, ${ }^{14}$ Pantnagar. ${ }^{15}$ In the present study identification and characterization of pathogen its incidence in seed grown in
Rajasthan state, India and transmission of seed borne inoculums from seed to plant were studied, ${ }^{10,16-20}$

\section{Materials and methods}

A survey was carried out to know the status of bacterial wilt in growing seasons of brinjal from farmer's field. All the naturally infected seeds and plant parts of brinjal were collected at different stages of growth from farmer's fields, houses and market. All the seed samples were categorised as asymptomatic, moderately discoloured and shrivelled discoloured seeds for the study. The seed and plant materials from various fields were collected and brought to laboratory for the isolation of the pathogen (s). The infected seed samples and infected plant tissues of leaves and fruits were surface sterilized and plated on Petri plates containing NA (Nutrient Agar) medium under aseptic conditions. Ninty seven seed samples of brinjal and infected plant material were subjected to dry seed examination, incubation on moistened blotters and TZC agar medium to find the incidence of RS in brinjal. The pure typical bacterial colonies were incubating at $30^{\circ} \mathrm{C}$ for $72 \mathrm{hrs}$ were subjected to various tests namely gram's staining, $\mathrm{KOH}$ solubility test, levan formation, oxidase test, ${ }^{21}$ potato soft rot test, nitrate reductase test, arginine dihydrolysis, gelatin hydrolysis test, hypersensitivity test in tobacco and pathogenecity tests ${ }^{22}$ for the 
identification of the bacterial species. For all the tests $24-48 \mathrm{~h}$ old cultures ${ }^{22}$ and bacterial suspensions were used. The bacterial isolates identified by various methods as described above were subjected to pathogenecity tests ${ }^{19}$ on the host plant and other plant species. The infected plant material like leaves, stem and fruits were surface disinfected and then rinsed in sterile distilled water. The bacterial isolates were purified by streaking a single colony of each isolate on NA medium ${ }^{23}$ and preserved for subsequent biochemical studies.

\section{Characterization of Ralstonia solanacearum (RS)}

Pathogenicity test: The pathogenicity test was performed on the detached leaves of brinjal. For the pathogenicity test single colony of RS showing virulent, fluidal, irregular and creamy white colour was selected for each group of isolates and multiplied in a NA medium. The 24 hours old bacterial cultures were suspended in sterile water was in filtered in leaves. In another experiment, the young seedlings were dipped into bacterial suspension for $24 \mathrm{hr}$ and incubated in a Petri dish at room temperature for at least 3-5 days for the appearance of symptom. The host range of RS isolates was tested in some other crops like chilli, tomato, okra for pathogenicity test. This test was performed to observe the reaction or infection ability of Pathogen on other than brinjal. Hypersensitivity response (HR) test was studied on tobacco (Nicotiana tabaccum) plants by infiltration of bacterial suspension into the intrveinal areas of the tobacco leaves to determine the pathogenic nature of the isolates, ${ }^{23,24}$

\section{Biochemical Studies}

In Gram staining reaction, $24 \mathrm{hrs}$ old bacterial cultures for each isolates were taken to perform the gram reaction test. Gram staining results were confirmed by potassium hydroxide test $(3 \% \mathrm{KOH})$. The bacteria were aseptically removed from Petri plates with tooth pick, placed on glass slide in a drop of $3 \% \mathrm{KOH}$ solution and stirred for 10 second using a quick circular motion of hand. For oxidase test, a loopful of bacterial colony ( $24 \mathrm{hrs}$ old) on nutrient agar taken and the inoculums was rubbed on filter paper pervaded with freshly prepared aqueous solution of Tetramethyl-p-phenylene diamine dihydrochloride..$^{22}$ In fluorescence test the ability of bacterial isolates to produced fluorescent pigment was studied on King's medium B. The non fouresecent isolates on King's medium B were transferred to Tetrazolium chloride agar (TZCA) medium. TZC agar medium (a semi-selective media for non-fluorescent pseudomonads) containing bacteriological peptone $(10 \mathrm{~g})$, casein hydrolysate $(1 \mathrm{~g})$, glucose $(5 \mathrm{~g})$, agar-agar $(15 \mathrm{~g})$ and 2,3,5-triphenyl tetrazolium chloride $(0.05)$ in 1 liter distilled water. The TZC is added as $1 \mathrm{ml}$ of a filter sterilized $0.5 \%$ solution per $100 \mathrm{ml}$ of molten sterilized media $\left(60^{\circ} \mathrm{C}\right)$ before pouring into Petri plates. All the inoculated plates were incubated for $48-72 \mathrm{hrs}$ at $30^{\circ} \mathrm{C}$ in BOD. ${ }^{25}$ The test bacterial isolates yielded irregular, fluidal, white, virulent colony with pink center on TZCA (tetrazolium chloride agar) medium suggested the presence of Ralstonia solanacearum. ${ }^{26}$ Plates were incubated at $27^{\circ} \mathrm{C}$ and the colonies were obtained after 3-4 days. The ability of bacterial isolates to grow at different selected temperature range at $27^{\circ} \mathrm{C}, 37^{\circ} \mathrm{C}$ and $41^{\circ} \mathrm{C}$ were tested. For levan test, Sucrose Peptone Agar or Nutrient Agar medium with 5\% sucrose is suitable substrate. A single colony for each isolate was stabbed with a sterilized tooth pick on NA medium containing 5\% sucrose and dome shaped colonies yielded. To study of Arginine dihydrolase activity, a fresh culture was stabbed into a soft agar tube of Thornley's medium, sealed with sterilized mineral oil or melted agar and incubated at $28^{\circ} \mathrm{C}$. A colour change from faint pink to red within four days is positive reaction. The pectolytic activity was studied by using well washed, healthy, firm potato slices; surface sterilized and was peeled aseptically. Three standard slices were placed in sterile petri dishes and incubated in a moist chamber. Two slices were then inoculated with loopful of bacteria of each isolate and incubated at room temperature for 24-48 hrs for the detection of soft rot symptoms. Pectolytic activity was performed to observe the condition of the sliced potato. In gelatin liquefaction test, gelatin medium containing beef extract $(13 \mathrm{~g})$, peptone $(5 \mathrm{~g})$, gelatin $(120 \mathrm{~g})$ added in 1 litre distilled water was used. The test tube containing 4-10 $\mathrm{ml}$ medium sterilized incubated at $27^{\circ} \mathrm{C}$.

\section{Results}

A total of 97 seed samples of 12 districts revealed asymptomatic $(07.75-97.50 \%)$ moderately discoloured (04.50-67.50\%) and shrivelled discoloured (03.25-34.75\%) seeds in dry seed examination (Table 1). Initial symptoms as oozing and browning at cotyledonary leaves, browning of leaf apex to reddish streak, on transition zone or hypocotyl region in seedlings was observed. In severe infection the hypocotyl and transition zone showed rotting but no prominent visible symptoms were observed on leaves except dropping leaves or apical part (Figure 1A) (Figure 1B). The heavily infected seedlings showed mortality as compared to asymptomatic seeds (Figure 1C,D,G). In severe infection the complete plant showed wilting symptoms (Figure-1L-N). In histo patholgical studies, the placenta and seed showed browning when the fruit bisect. Preliminary, morphological appearance showed bacterial wilting symptoms has shown the presence of bacterial strains resembling to Ralstonia solanacearum.

\section{Isolation and identification of Ralstonia solanacearum isolates}

A total of thirty two isolates of RS were obtained from the infected seed samples, plant parts, roots and stem of brinjal collected from 12 districts surveyed. All the 32 morphologically identical isolates from infected brinjal seeds and plant parts produced cream color or offwhite color colonies on NA medium classified in 7 groups.

\section{Confirmative test of Ralstonia solanacearum}

Pathogenicity test: The results of pathogenicity test revealed that all the isolate of 7 groups of RS were able to cause wilting symptoms on brinjal leaves identified (Figure 1), (Table 2). The host range of RS was determined by pathogenicity test on detached leaves of another host like chilli, tomato, okra etc. The result showed RS causing wilting symptoms on brinjal leaves but not produce any symptom on the leaves of these said hosts (Table 2). The results of Hypersensitivity response (HR) test showed positive reaction and induce HR of tissues into the interveinal areas between of tobacco.

\section{Biochemical tests}

Mainly two types of colonies

a. Rough, dry and flat type and

b. Fluidal and elevated types were produced on complex media.

The test bacterial isolates yielded irregular, fluidal, white, virulent colony with pink center (avirulent colonies were without pink center) on TZCA (tetrazolium chloride agar) medium suggested the presence of Ralstonia solanacearum (Figure 1A-N). It is a non-fluorescent Pseudomonas with a polar tuft of flagella (Figure 1H). Cells are non-pigmented, but diffusible brown pigment was produced (Figure 
1E). Potassium hydroxide solubility test revealed an elastic thread or viscous thread was observed by all RS isolates and gram negative straight or curved rod shaped which is the characteristic feature of any plant pathogenic bacteria and all the isolates were gram negative (Table 2), (Figure 1I). The results of oxidse test showed positive response means all isolates were able to develop color with oxidase reagent within few seconds which indicated that the result of the test was positive. In fluorescence test, a fluorescent green pigment, water soluble under long wave length $(366 \mathrm{~nm})$ under UV lights and result found negative means its non fluorescent bacteria. Gelatin liquefaction test containing bacterial pathogen was found liquefaction weak positive. In temperature sensitivity test, the isolates of grew blew $40^{\circ} \mathrm{C}$. All isolates were not able to produce distinctive domed shaped or round colonies on sucrose containing NA medium in levan test (Table 2). Arginine dihydrolase activity by the bacterium showed not to change $\mathrm{pH}$ and colour (Figure1J).
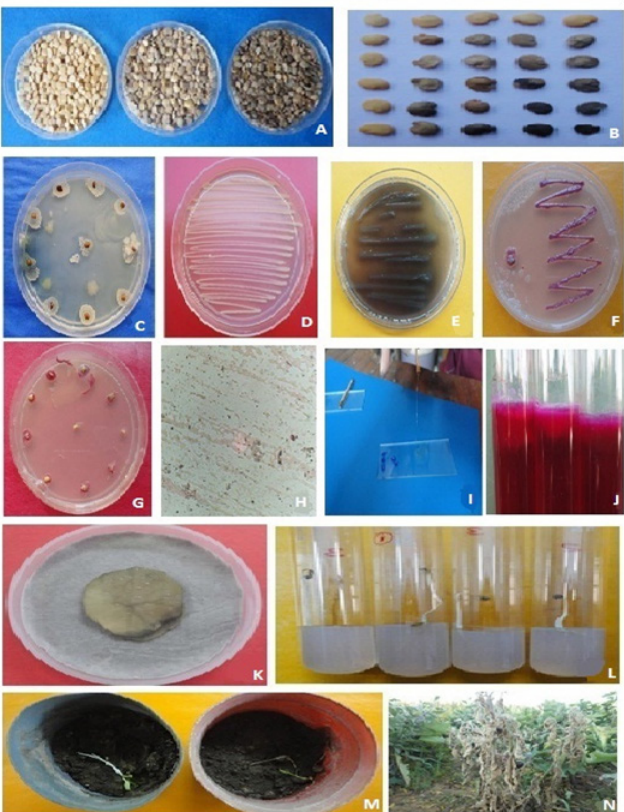

Figure I Isolation, identification and Infection of Ralstonia solanacearum in brinjal seeds A,B-Seed categorization as asymptomatic (upper left), moderate discolored (middle) and shrivelled heavily discolored (upper right); C,D-bacterial colonies around seed on NA medium and streaking; E-bacterial colonies producing the brown diffusible pigment (streaking on NA); F,G-Streaked bacterial colonies on TZC Agar medium with pink centre (Figure F), (Figure H) (Figure I)-showing Gram's staining and $\mathrm{KOH}$ solubility test; J-Arginine dihydrolyase test; K-potato soft rot test; L,M-seedling symptoms and mortality on test tube seedling test (TTSST) and pot experiment; $\mathrm{N}$-wilting symtoms on plant in the field.

Table I Incidence of Ralstonia solanacearum in the seeds of brinjal in Rajasthan state, India

\begin{tabular}{llll}
\hline District & Total No. of sample & No. of seed samples infected & Incidence on TZCA medium \\
\hline Jaipur & 49 & $49(03.25-34.25)$ & $49(13-100)$ \\
Dausa & 4 & $04(12.25-25.50)$ & $04(30-80)$ \\
Tonk & 5 & $05(06.75-14.50)$ & $05(20-90)$ \\
Jhunjhunu & 5 & $05(05.25-13.75)$ & $05(40-100)$ \\
Kota & 5 & $05(08.75-19.25)$ & $05(30-85)$ \\
Alwar & 2 & $02(08.25,10.75)$ & $02(40-75)$ \\
Sikar & 6 & $06(05.25-34.75)$ & $06(40-85)$ \\
Jalor & 5 & $05(06.25-21.75)$ & $05(30-100)$ \\
Nagaur & 3 & $03(07.25-18.00)$ & $03(45-80)$ \\
Bikaner & 8 & $08(08.75-29.75)$ & $08(20-90)$ \\
Jodhpur & 2 & $02(11.25-17.50)$ & $02(30,70)$ \\
Ajmer & 3 & $03(09.25-21.75)$ & $03(50-100)$ \\
\hline Total & 97 & $97(03.25-34.75)$ & $97(30-100)$ \\
\hline
\end{tabular}


Table 2 Biochemical tests of bacterial isolates and their characteristics of brinjal to identify the bacterial species

\begin{tabular}{|c|c|c|c|c|c|c|c|c|c|c|c|c|c|c|}
\hline $\begin{array}{l}\text { S. } \\
\text { No. }\end{array}$ & $\begin{array}{l}\text { Bacterial } \\
\text { isolates }\end{array}$ & $\begin{array}{l}\text { Gram's } \\
\text { staining }\end{array}$ & $\begin{array}{l}\mathrm{KOH} \\
\text { solubility } \\
\text { test }\end{array}$ & $\begin{array}{l}\text { KMB } \\
\text { fluorescence } \\
\text { test }\end{array}$ & TZCA & $\begin{array}{l}\text { Tween- } \\
80\end{array}$ & $\begin{array}{l}\text { Color } \\
\text { pigment }\end{array}$ & $\begin{array}{l}\text { Levan } \\
\text { form- } \\
\text { ation }\end{array}$ & $\begin{array}{l}\text { Potato } \\
\text { soft } \\
\text { rot } \\
\text { test }\end{array}$ & $\begin{array}{l}\text { Arginine } \\
\text { dihyd- } \\
\text { rolysis }\end{array}$ & $\begin{array}{l}\text { Toba- } \\
\text { cco } \\
\text { HR } \\
\text { test }\end{array}$ & $\begin{array}{l}\text { Starch } \\
\text { hydro- } \\
\text { lysis }\end{array}$ & $\begin{array}{l}\text { Gelatin } \\
\text { liquifi- } \\
\text { cation }\end{array}$ & $\begin{array}{l}\text { Growth } \\
\text { temp. } \\
\left({ }^{\circ} \mathrm{C}\right) \\
4-40^{\circ} \mathrm{C}\end{array}$ \\
\hline 1 & $\mathrm{~A}$ & - & + & - & + & - & - & - & - & + & + & - & + & + \\
\hline 2 & $\mathrm{~B}$ & - & + & - & + & - & - & - & - & + & + & - & + & + \\
\hline 3 & $\mathrm{C}$ & - & + & - & + & - & - & - & - & + & + & - & + & + \\
\hline 4 & D & - & + & - & + & - & + & - & - & + & + & - & + & + \\
\hline 5 & $\mathrm{E}$ & - & + & - & + & - & + & - & - & + & + & - & + & + \\
\hline 6 & $\mathrm{~F}$ & - & + & - & + & - & + & - & - & + & + & - & + & + \\
\hline 7 & $\mathrm{G}$ & - & + & - & + & - & - & - & - & + & + & - & + & + \\
\hline
\end{tabular}

\section{Discussion}

Bacterial wilt caused by Ralstonia solanacearum ${ }^{4}$ is predominant disease in warm humid tropical and temperate regions of the world. ${ }^{6,7}$ It has been reported worldwide, ${ }^{9,10,12,13,20}$ including India. ${ }^{14,15}$ Ninty seven seed samples of brinjal collected from 12 districts of Rajasthan were studied by dry seed examination, incubation on moistened blotters ${ }^{2}$ and $^{25}$ TZC (Tetra Zolium Chloride Agar) agar plate method to find the incidence of pathogen. These plates were subjected to various tests namely gram's staining, $\mathrm{KOH}$ solubility test, levan formation, oxidase test ${ }^{21,27}$ potato soft rot test, arginine dihydrolysis. ${ }^{28}$ For all the tests $24-$ $48 \mathrm{~h}$ old cultures ${ }^{22}$ and bacterial suspensions ${ }^{29}$ were used. The bacterial isolates identified by various method a described above were subjected to Pathogenicity test ${ }^{30}$ was studied on the host plant and other plant species. Pathogenicity test (Host Test) on bean, tomato, potato and chilli crops by stab inoculation method and smothering of seeds. All the bacterial colonies isolated from of brinjal seeds has been cultured on nutrient agar (NA) then subjected to grow on $5 \%$ sucrose nutrient agar (SNA) for the study of levan formation. The $\mathrm{KOH}$ technique is far easier and faster to distinguish gram negative and gram positive bacteria than the traditional Gram-strain in which dyes are employed ${ }^{31}$ and this test indicated that the isolates of Ralstonia solanacearum. The pathogen (RS) showed negative reaction in arginine dihydrolase test. ${ }^{22}$ Similar results were reported in chilli, tomato and okra. ${ }^{20,32}$ The colonies that were levan negative grown on King's medium B. The colonies under UV light on KMB, Gram's staining and Gram's $\mathrm{KOH}$ solubility test suggested that the bacterium under test was nonfluorescent bacterium. The negative hydrolysis of starch and negative results of nitrate reduction test and oxidase (Kovac's) test suggested that the test bacterium might be non-fluorescent pseudomonads. The growth of test isolates on TZC (Tetrazolium chloride) agar medium suggested the absence of xanthomonads. The non-fluorescent Pseudomonas on brinjal is reported to be Ralstonia solanacearum that showed the prominent wilting symptoms on plant. The test bacterial isolates yielded irregular, fluidal, white, virulent colony with pink center (avirulent colonies were without pink center) on TZC agar medium suggested the presence of Ralstonia solanacearum. ${ }^{26}$ Results of LOPAT test carried out in this investigation as suggested by $^{22}$ confirmed the bacterium isolates to be Ralstonia solanacearum. It was observed that seed germination was delayed in symptomatic seeds as compared to asymptomatic seeds. Initial symptoms were as oozing, browning at cotyledonary leaves, brown to reddish strak, on transition zone or hypocotyl region was observed. In severe infection the hypocotyl and transition zone showed rotting. In the heavily infected seedlings the symptoms and mortality were high as compared to asymptomatic seeds. It was observed in transmission studies that in severe infection the complete plant showed wilting symptoms, no flower setting, low or aborted fruits due to the impact of pathogen. ${ }^{33,34}$

\section{Conclusion}

The findings of the study clearly indicated that bacterial wilt of brinjal is caused by Ralstonia solanacearum seems a great threat for raising quality and healthy plants and seeds of brinjal in order to get higher fruit production. The management strategies still not developed due to lack of the identification of the causal organism because the pathogen not produced any prominent visible symptoms on plant or plant parts initially except wilting symptoms and finally the host died. The findings of the present study would definitely be useful to design a comprehensive molecular based analysis of the pathogen and to adopt a proper management strategy suitable for the integrated disease management programs.

\section{Acknowledgements}

Authors are grateful to Prof. Ashok Sharma, hon'ble vicechancellor, VMOU, Kota, Prof. Kailash Agrawal Head, Department of Botany, University of Rajasthan, Jaipur, faculty members of staff of regional centre Jodhpur, P.G. Department of Botany, Agrawal PG College, Jaipur for valuable support and academic guidance. Thanks to Dr. Meena, Sh. Kailash Chaudhrary and Sh Mahesh Kumar for the valuable technical support in writing this research article.

\section{Conflict of interest}

The author declares there is no conflict of interest.

\section{References}

1. Kochhar SL. Economic Botany in the tropics. Macmillan India Limited, Daryaganj, New Delhi; 2004; 604 p.

2. Anonymous. National Horticulture Board Annual Report. 2005. FAO Data. (http://faostat.fao.org/). 2011:5-6.

3. Anonymous. International rules for seed testing. International Seed Testing Association (ISTA). Seed Science and Technology. 1985;13:299-355.

4. Yabuuchi E, Y Kosako, I Yano, et al. Transfer of two Burkholderia and an Alcaligenes species to Ralstonia gen. Nov.: Proposal of Ralstonia pickettii (Ralston, Palleroni and Doudoroff 1973) comb. Nov., Ralstonia solanacearum (Smith 1896) comb. Nov. and Ralstonia eutropha (Davis 1969) comb. Nov. Microbiol Immunol. 1995;39(11):897-904.

5. Hayward AC. Research on Bacterial Wilt: A perspective on International links and access to literature. In: Bacterial Wilt Disease and the Ralstonia solanacearum species Complex. Allen C, editors. The American Phyto pathological Society, 3340 Pilot Knob Road, St. Paul, Minnesota, USA; 2005;1-8.

6. Hayward AC. Biology and epidemiology of bacterial wilt caused by Pseudomonas solanacearum. Annu Rev Phytopathol. 1991;29:65-87.

7. Hayward AC. The hosts of Pseudomonas solanacearum. In: Bacterial 
wilt: the disease and its causative agent, Pseudomonas solanacearum. AC Hayward et al. editors. CAB International, Wallingford, UK. 1994;9-25.

8. Allen C, Prior P, Hayward AC. Bacterial Wilt Disease and the Ralstonia solanacearum species Complex. Journal of Phytopathology, 3340 Pilot Knob Road, St. Paul, Minnesota, USA; 2005.

9. Richardson MJ. An annotated list of seed-borne diseases, $4^{\text {th }}$ ed. Pro. lnt. Seed testing association, Zurich, Switzerland; 1990;376 pp.

10. Bradbury JF. Guide to plant pathogenic bacteria. CAB International Mycological Institute (CMI), UK. 1986;332.

11. Balogun OS, Fanehinmi OA. Influence of seedling age at infection and watering frequency on growth and yield Responses of eggplant to cucumber mosaic virus, African J of General Agriculture. 2007;4(3).

12. Rakib A, Mustafa AA, Adhab Aet al. Antiviral activity of vit org, 2-nitromethyl phenol and Thuja extract against eggplant blister mottled virus (CBMV). African J of Microbiology Research. 2011;5(21):35553558

13. Begum N, Haque MI, Mukhtar T, et al. Status of bacterial wilt caused by Ralstonia solanacearum in Pakistan. Pak J Phytopathol. 2012;24(1):11-20.

14. Chakravarty G, Kalita MC. Comparative evaluation of organic formulations of Pseudomonas fluorescens based biopesticides and their application in the management of bacterial wilt of brinjal (Solanum melongena L.). African J of Biotechnology. 2011;10(37):7174-7182.

15. Sitaramaiah K, Sinha SK. Relative efficacy of some selected antibiotics on bacterial wilt (Pseudomonas solanacearum race 3) of brinjal. Indian J Mycol Plant Path. 1983;13:277-281.

16. Schaad NW, Kendrick R. A qualitative method for detecting Xanthomonas campestris in crucifer seed. Phytopathology. 1975;65(9):1034-1036

17. Neergaard P. Seed Pathology. The Macmillan Press Ltd., London; 1987; 1187 p.

18. Richardson MJ. An annotated list of seed-borne diseases Phytopathological Papers, Commonwealth Mycological Institute. 1979;23:320 pp.

19. Schaad NW. Detection of Xanthomonas campestris pv. campestris in crucifer, In: detection of bacteria in seed and another planting material. Phyto pathology. 1989;68-75.

20. Sharma N, Sharma DK. Incidence and seed transmission of Ralstonia solanacearum (Smith) in brinjal (Solanum melongena L.) seeds. International Journal of Plant Pathology. 2014;5(2):63-69.

21. Kovacs N. Identification of Preudomonas pyocyanea by the oxidase reaction. Nature. 1956; 178(4535):703.

22. Lelliot RA, Stead DE. Methods for the diagnosis of bacterial diseases of plants, In: Methods in Plant Pathology, ed. Blackwell Scientific Publication, Oxford London; 1987; 216 p.

23. Klement A, Goodman R. The hypersensensitivy reaction to infection by bacterial plant pathogens. Annual Review of Phytopathology. 1967;5:17-44.

24. Gvozdyak, Pasichnyk, Khodos et al. Effect of physiological state of bacteria and heavy metals on hypersensitive reaction on the tobacco leaf. Mikrobiol Z. 2001;63(6)25-31.

25. Kelman A. The relationship of pathogenicity in Pseudomonas solanacearum to colony appearance on a tetrazolium medium. Phytopathology. 1954;44:693-695.

26. Mehan VK, McDonald D. Techniques for diagnosis of Psuedomonas solanacearum and for resistance screening against groundnut bacterial wilt (edt. Tech. Manual no.1). International Crops Research Institute for the Semi-Arid Tropics (ICRISAT) AP, India; 1995; 846 p.

27. Hildebrand DC, Schroth MN. Identification of fluorescent pseudomonas. In: Proc. of the $3^{\text {rd }}$ Int. Conference on plant pathogenic bacteria (ed. Mass Gusleranus HP.), centre for Agricultural Publishing and Documentation, Wageningen, The Netherlands; 1972. 281-287 p.

28. Thornley MJ. The differentiation of Pseudomonas from other gram negative bacteriaon the basis of Arginine metabolism. J Appl Bacteriol. 1960;23(1):37-52.

29. Kiraley Z, Kumenl Z, Solymosy E, et al. Methods in plant pathology Akademiai Kiado, Budapest; 1970; 509 pp.

30. Schaad NW. Laboratory guide for identification of plant pathogenic bacteria, ed. for bacteriology committee of American, Phytopathological society. St. Paul, Minisota. 1980;72.

31. Suslow TV, Schroth MN, Isaka MH. Application of rapid method for gram differentiation of plant pathogenic and saprophytic bacteria without staining. Phytopathology. 1982;72(7):917-918.

32. Sharma DK. Seed-borne and post-harvest bacterial diseases of chilli (Capsicum spp.) and tomato (Lycopersicon esculentum Mill.) crops and there management. Ph.D. Thesis, Univ. of Rajasthan, Jaipur; 2007;103107.

33. Ayers SH, Rupp P, Johnson WT. A study of the alkali forming bacteria in milk. U.S. Dept of Agric. Bull. 1919;782.

34. Young JM, Triggs CM. Evaluation of determinative tests for pathovars of Pseudomonas syringae van Hall 1902. J Appl Bacteriol. 1994;77(2):195-207. 